\title{
Luther and Calvin on predestination: A comparison
}

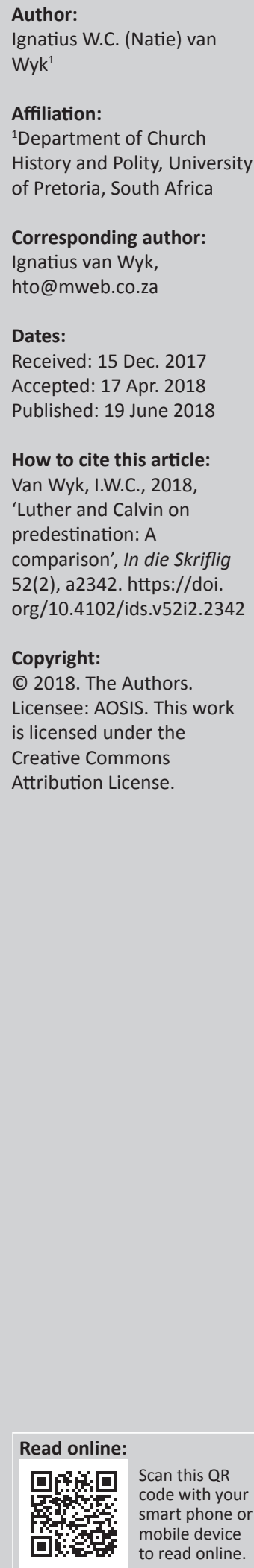

\begin{abstract}
Alexander Schweizer propagated the thesis that predestination is a central theme of Calvin's theology and that later Calvinism had to defend his teaching as the distinguishing point between the Lutheran and reformed traditions. In this article it is shown that election is also an important element of Luther's theology. The historic development of the two reformers' thinking about election is presented. In spite of different nuances, the difference between the two are minimal. The main reason why the differences could be underplayed is because it is shown that Calvin's thesis of 'double predestination' only forms one part of Calvin's doctrinal thinking on this subject. Calvin has actually two sets of statements on predestination. When the unacceptable statements about 'double predestination' are not emphasised, but rather his early works and sermons, he and Luther share the same opinions on election in Christ through grace. Both of them understand election as the final word on justification.
\end{abstract}

\section{Introduction}

Until the Barthian revolution $^{1}$ altered the theological landscape in the 1920s, it was widely assumed that the distinguishing feature of reformed theology was the prominence given to the doctrine of predestination - and more specific 'Calvin's doctrine of double predestination'. The decisive impetus to this opinion was given in 1844 by Alexander Schweizer in the first volume of his Glaubenslehre der evangelisch-reformierten Kirche. In Schweizer's view (1844:38-43), what distinguished the theology of the reformed churches from Lutheran theology, was a different approach towards the most fundamental question (Grundrichtung). Lutheran theology wanted to overcome 'Judaizing' by claiming that justification does not occur by works, but by faith. Reformed theology on the other hand, was centrally concerned with the 'paganisation' of the church through the divinisation of the creature (e.g. the fundamentally polytheistic worship of May and the saints). From this initial difference in Grundricthung, a further difference in 'material principle' arose. ${ }^{2}$ According to Schweizer the 'material principle' of Lutheran theology was the doctrine of justification by faith alone, whereas for reformed theology, it was the 'sense of absolute dependence upon God alone' which was articulated dogmatically in the doctrine of predestination. The difference in 'material principle' is directed to two different basic questions which determine the shape of each theology taken as a whole. The Lutheran question was: What is it in humankind that makes blessed? The answer was faith, not works. The reformed question was: Who makes blessed or damns, the creature or God alone?; and the answer was, God alone. Therefore, Schweizer (1844:42) concluded that Lutheran theology was anthropological in character, while reformed theology was theological in character. ${ }^{3}$

Alexander Schweizer's thesis influenced theological opinions for centuries. The animosity between reformed and Lutheran theologies, which could still be traced in South Africa, has to do with these type of dramatic slogans that could not be traced back to Luther and Calvin themselves. The aim of this contribution is to show that election and predestination ${ }^{4}$ were important themes to both Calvin and Luther, but that neither of them elevated these themes to the highest point of a hierarchy of dogmatic themes. Careful historical research shows that Luther and Calvin were much closer in their approaches towards these themes than what the apologists of these 'confessions' have suggested in the past.

1. Reformed scholars such as Brouwer (2016:44, 50-58), Kim (2013:11) and Muller (2013:144-146) continue with this claim in spite of the fact that Wendel (1980 [1950]:264) refuted this thesis decades ago.

2.Compare McCormack (1999:472, footnote 4) for an explanation of this concept.

3.Compare McCormack (1999:473, footnote 5) for comprehensive information.

4.The terminological difference between election and predestination has to do with the fact that the doctrine of election only concentrates on the destination of people towards salvation, while the doctrine of predestination deals with the destination of people salvation or perdition (Härle 2000 [1995]:505). 


\section{Martin Luther Introductory remarks}

By looking at Rieger's new handbook (2017) on the basic concepts of Luther, one gets the impression that Luther did not write a lot about election and predestination. According to him (Rieger 2017:65-66), Luther dealt only a few times with these questions. Rieger's overview is, however, misleading. Luther wrote more about these themes than Rieger suggests. Some scholars (Exalto 1982:163; Kim 2013:73) even argue that these themes were often in the reformer's thoughts, because he understood predestination as the completion of justification. Luther was a serious biblical scholar. He (2006 [1525]:284, WA 18, 632, 23-32) was of the opinion that one should give attention to these themes, because they are biblical. One of the greatest Luther scholars of all times, Gerhard Ebeling (1979:521-528), even indicates that predestination is the final test for theological thinking. He is of the opinion that predestination should be the final word in a dogmatic handbook, because finally, we are left with the mystery of God's love and judgement, his mercy and exclusion from his kingdom - and in this predicament it is important to hear: 'You are elected'!

\section{The historic development of his thoughts on predestination}

It is well documented that Martin Luther was afflicted by the question on predestination during his time as monk and priest. His father confessor, Johannes von Staupitz, helped him to deal with God's incomprehensible will (cf. Leppin 2010 [2006]:72-89). ${ }^{5}$ Luther (1913 [1531-1546], WA TR 2.1490, $112,9-16)$ recalls in one of his table talks a discussion with Von Staupitz on predestination:

\begin{abstract}
Ego semel conquerebar de sublimtate praedestinationis Staupitio meo. Respondit mihi: In vulneribus Christi intelligitur praedestinatio et invenitur, non alibi, quia scriptum est: Hunc audite. Der Vater ist zu hoch, sed dixit Pater: Ego dabo viam veniendi ad me, nempe Christum. Ite, credite, hengt euch an den Christum, so wirts sichs wol finden, quis sim, suo tempore. Das thun wir nicht, ideo Deus est nobis incomprehensibilis, incogitabilis; er wirt nicht begriffen, er will ungefast sein extra Christum. [I once complained to my Staupitz about the sublimity of predestination. He answered me: One understands and finds the predestination in the wounds of Christ, and nowhere else, for it is written: 'Listen!' The Father is too high, but the Father has said: I will give you a way to come to me - that is Christ. Go, believe, and embrace Christ, in this way you will indeed find out who I am at this stage. Should we not do this, then God would remain incomprehensible, unthinkable; He would not be understood; outside Christ He does not want to be grasped.] (p. 112, [author's translation])
\end{abstract}

His initial difficulty and conflict (Anfechtung) with God's predestination continued to plague him in later years. He, however, kept dealing with this problem in the same way as Von Staupitz taught him. He did not look for a rational answer, but for an answer coming from faith in Jesus Christ.

\footnotetext{
5.An important reference in this regard is Luther's 'table-talk' nr. 5658 a 11919 [1531-1546]:293, WA TR 5, 293,28-30). This 'table-talk' is actually a part of [1531-1546]:293, WA TR 5, 293, 28-30). This 'table-talk' is actually a part of
his lecture on Genesis 26:9 (1912 [1538/1542]:461, WA 43, 461, 11-16). For an his lecture on Genesis 26:9 (1912 [1538/1542]:461, WA 43, 461, 11-
in-depth study on Von Staupitz - Luther - election, see Wriedt (1991).
}

In 1519 Luther (2012 [1519], WA 2, 685-697) wrote Ein Sermon von der Bereitung zum Sterben [A sermon on the preparation of death]. In this small booklet he pays attention to election in the section that deals with eternal hell. He states that one should not be concerned about the many people who are not elected and who are going to perish in hell. One should not concentrate on this terrible predicament and fear that you might be part of this group of people. One should rather let God be God, and that is to allow him to know more about you than what you could know about yourself. You should look at Christ! He descended to hell where he was totally separated from God and cried out 'Eli, Eli, lama asabthani?' In this image your 'hell' - your uncertainty about your own election - is overcome. Therefore, concentrate through faith on Christ, and you will overcome the fear of not being elected. By looking at God's grace in Christ, you will be certain that you are elected alongside the holy people around his throne. ${ }^{6}$

In 1525 Luther published one of his major works called De servo arbitrio ${ }^{7}$ [The bondage of the will]. In this work, he makes important remarks concerning predestination. The first important remark is that the theme under discussion is important to Christians. He (2006 [1525]:250, WA 18, 615, 13-16) argues that it is necessary and salutary to know that God does not foreknow contingently, but that he knows, decides and executes everything by his infallible, eternal and unchangeable will. ${ }^{8}$ Luther's second important remark (2006 [1525]:282, WA 18, 631, 42-632, 2) ${ }^{9}$ has to do with the insight that election has to do with God's secrets that could not be investigated. His decisions are obscured and not revealed in Scripture. One should therefore keep quiet about

6.Luther's own words in the modernised version of T. Dietz (2012 [1519]:57-59, WA 2, 690, 11-31) are:

Zum Zwölften darfst du die Hölle und die Ewgkeit des Leidens samt der Verwerfung nicht in dir, nicht an sich und nicht in denen, die verdammt sind, ansehen; auch darfst du dich nicht bekümmern wegen so vieler Menschen in der ganzen Welt, die nicht erwählt sind [...] Darum musst du hier stark sein und die Augen fest gesclossen halten vor solchem Anblick. Denn es ist zu gar nichts nütze, wenn du dich auch tausend Jahre darin übst, am Ende verdirbt er dich doch. Du musst doch Gott Gott sein lassen und zulassen, dass er mehr von dir wei $\beta$ als du selbst. Darum sieh das himmlische Bild Christi an, der um deinetwillen in die Hölle gefahren ist und von Gott verlassen war wie einer, der auf ewig verdammt ist, and am Kreuz und von Gott verlassen war wie einer, der auf ewig verdammt ist, and am Kreuz sprach: Eli, Eli, lama asabthani, O mein Gott, o mein Gott, warum hast du mich verlassen? Siehe, in diesem Bild ist deine Hölle überwunden und deine ungewiss Erwählung ist gewiss gemacht. Wenn du dich allein darum kümmerst und glaubst, es sei für dich geschehen, so wirst du ganz gewiss in diesem Glauben bewahrt. Darum verliere das ja nicht aus den Augen und suche dich nur in Christus und nicht in dir, dann wirst du dich ewig in ihm finden. Und wenn du Christus und alle seine Heiligen ansiehst und dir wohl gefällt die Gnade Gottes, der sich doch erwählt hat, und ganz fest in diesem Wohlgefallen bleibst, so wirst auch du schon erwählt sein.

7.This title could be translated in more than one way. The German translation of the title in Luther (2006 [1525]:219) reads, 'Vom unfreien Willensvermögen'. To translate this as 'On the lack of freedom of the human will' would not be absolutely correct. According to the editor, Wilfried Härle (2006:XLI), 'arbitrio' is traditionally translated as 'will', although 'arbitrium' and 'voluntas' are not exactly the same. 'Arbitrium' means the ability to referee out of a neutral position on good and evil, 'Arbitrium 'means the ability to referee out of a neutral position on good and evil right and wrong. It is therefore the ability to dedicate yourself towards a chosen goal in life. The words 'Willensvermögen' and 'Wahlvermögen' (it is the ability to choose or the ability of dedication) would therefore be correct translations. The first German translation of Justus Jonas (December 1525), had the title Dass der freie

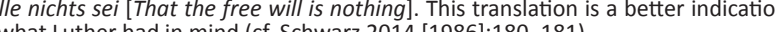
of what Luther had in mind (cf. Schwarz 2014 [1986]:180-181).

8.In Luther's own words: 'Est itaque et hoc imprimis necessarium et salutare Christiano, nosse, quod Deus nihil praescit contingenter, sed quod omnia incommutabili et aeterna, infallibilique voluntate et praevidet et proponit et facit.'

9.Luther says:

Cur non ab inquirendis illis contines ipse et absterres alios, quae Deus occulta nobis esse voluit, et scripturis non prodidit? Hic oportuit os digito compescere, revereri, quod lateret, adorare secreta maiestatis consilia et cum Paulo clamare, $\mathrm{O}$ homo, tu qui es, qui contendas cum Deo? 
his decisions, honour what he hides and venerate his secret plans and majesty, because man should not bring God to justice. Luther's third argument (2006 [1525]:284, WA 18, 632, $24-29)^{10}$ is that believers will not have a problem with God's election, because they know that God is just and that he harms no one. For that reason there is no reason to investigate God's will - it should only be venerated and praised. Fourthly, Luther's positive view of God's will is grounded in his biblical understanding of God. The biblical revelation of God shows that he is ultimately gracious, compassionate and merciful (cf. especially Luther 2006 [1525]:400, WA 18, 683 on Ezekiel and Psalms 28 and 68 concerning the Deo misericordia). The will of the compassionate God is known due to the preaching of the Word. It is therefore not hidden or concealed (Verborgen), but revealed. This distinction between the 'hidden God' (Deus absconditus) and the 'revealed God' (Deus revelatus) is one of the secrets to Luther's understanding of predestination. ${ }^{11}$ God's will to elect and to show compassion is not a secret. Through the preaching of his Word, we know his will. There is no need to investigate this will; we should only venerate it in humbleness. ${ }^{12}$ It is the 'philosophical God', defended by Scholasticism, whose will is in darkness and needs philosophical investigation. In this regard, Luther (2006 [1525]:404, WA 18, 685, 7) makes a famous statement: ${ }^{13}$ 'Quae supra nos, nihil ad nos' ['what is above us, is none of our business']. He argues that what is not revealed to us about God and his will, is not our concern. It is senseless to speculate about the numbers of elected and rejected, but also about the question why certain people do not believe the gospel and whether these people would ultimately share in salvation or not. What our concern in life should be, is to listen to the preaching of the gospel and to praise God for his mercy. It is not our concern what God is or is not. We should not try to investigate why God does not save the whole human race. The reasons for election and predestination are not our concern. Luther (1912 [1538/1542]:463, WA 43, 463, 3-17 on Gn 26:9) would later, in his lectures on Genesis, repeat this viewpoint by saying: 'non esse inquirendum de praedestinatione Dei absconditi' ['there is nothing to be inquired about the predestination of God in his obscurity']. Finally, Luther (2006 [1525]:266, 656-660, WA 18, $625,11-17,786-787)$ remarks that this debate is far more important than bread and butter matters, because it has to do with the eternal things of God. These 'eternal things' have inter alia to do with the fact that we are sinners and totally depended upon the grace of God in Jesus Christ. Theologians

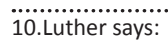

[...] Deus voluit ea vulgari, voluntatis verbo divinae rationem quarendam non esse, sed simpliciter adorandam, data gloria Deo, quod cum sit iustus et sapiens solus nulli faciat iniuriam, nec stulte aut temere quippiam agere possit, licet nobis longe secus appareat, hac responsione pii sunt contenti.

11.This distinction is not only an important pillar in his thoughts on predestination, but also a cornerstone of his whole theology (cf. Barth 2009:193-229; Exalto 1982:166-172; Lohse 1999 [1995]:215-218).

12.Luther (2006 [1525]:404, WA 18, 685, 38-44;) refers to Ezekiel and says:

[...] [Q]ui de praedicata et oblata misericordia Dei loquitur, non de occulta illa et metuenda voluntate Dei, ordinatis suo consilio, quos et quales praedicatae et oblata misericordiae capaces et participes esse velit. Quae voluntas non oblatae misericordiae capaces et participes esse velit. Quae voluntas non maiestatis divinae, soli sibi reservatum, ac nobis prohibitum, multo religiosius, quam infinitae multitudinis specus Coricii.

13.For comprehensive information about this dictum, see Jüngel (1980). may not be as learned as some philosophers (read Erasmus), but they know the truth of the gospel - and the notion of predestination is one aspect of that truth.

To summarise: Election is the doctrine of God's gracious and unconditional choice of those who are brought to faith by the Holy Spirit to be his children. Luther holds that believers can attribute their salvation ultimately to God choosing them although he rejects the idea that God also predestines those who do not believe to damnation. No one should try to fathom the mystery of God choosing his own (Kolb, Dingel \& Batka 2016:642).

\section{John Calvin Introductory remarks}

Calvin (Inst III.21.3), as Luther, gave attention to the themes of predestination and election, because they are biblical themes. He therefore argued that one should not keep Christians away from these notions, because one would then prevent exposure to the work of the Holy Spirit. Later, Calvinism ${ }^{14}$ created the impression that predestination is the central theme in Calvin's theology and that the debate on this theme originated with him. Recent research (Hesselink 2004:83; Link 2009:33; McGrath 1998 [1990]: 166-167; Plasger 2008:89-90), however, shows that the doctrine of predestination is not the central theme in Calvin's theology and that he relied a great deal on Augustine for his insights. Where he did deal with this theme, his aim was to provide certainty (Gewißheit) to the believer, and not to inquire about God's secrets. He therefore showed interest in the doctrine of predestination for practical and not speculative reasons. The question that troubled him was: How is it possible that when people hear the gospel, one accepts it and another rejects it? His answer was that some people simply reject the Word, while others, through the work of the Holy Spirit, embrace it. He then concluded that some people are elected, while others are rejected. Calvin formulated this belief in the so-called doctrine of double predestination (praedestinatio gemina). He first formulated it in his first catechism of 1538 (Hesselink 1997 [1538]) and continued defending it up to the Institutes of 1559 . He, himself (Inst III.23.7), referred to God's decree of rejection as a 'dreadful decree' (decretum horribile), but he was convinced that Paul teaches this in Romans 9:6-24. As we will see below, Calvin did not, however, teach that there is a symmetry between election and reprobation as taught by some later Calvinists. Nor was he (cf. (Hesselink 1997 [1538]) - 1538 Catechism, art. 13) interested in the question who is elected and not elected. Calvin (Inst. III.24.5), long before Karl Barth and in collegiality with Melanchthon (2011 [1559]:324-332; cf. Van Wyk 2015:12-16), taught election

14.Compare Brouwer (2016:50-58), Muller (2013) and Trueman (2013) for short overviews on developments within the reformed tradition. According to McGrath (1998 [1990]:208-218) the with (1998 [1990]:208-218) there are two reasons why this notion became important to the Calvinistic tradition: (1) The sociological reason has to do with the need of this confessional group to legitimise its own, separate existence. This doctrine helped to safeguard the identity of this social grouping. (2) The theological reason has to do with the need to show the internal consistency and coherence of Calvinism. It had to prove why two separate theological traditions need to exist within the broader Protestant movement. 
from an Christological perspective. This argument will receive special attention in order to present a more balanced view of Calvin's doctrinal thinking than in the past.

\section{The historic development of his thoughts on predestination}

Calvin's first contribution on predestination in the Institutes of 1536 unfortunately does not receive the attention it deserves. This early contribution is of great value for the present-day discussions on ecclesiology and soteriology. ${ }^{15}$ In this publication, Calvin discusses predestination as a section of his ecclesiology. He states that the 'church is the congregation of God's elect'. The church is not 'the elected church, but the window of election' (OS 1, 86-87). Calvin (OS 1, 89) also knows that there are people who do not belong to the visible church. These people will most probably perish. Only God, however, knows who these people are. At this stage, there was no mention of an ecclesia invisibilis, but Calvin $(O S 1,91)$ insisted that the existence of the church is a matter of faith. Calvin $(O S 1,88)$ argues that predestination is an important theme, because it would have no meaning for people to 'believe the church' but 'do not believe that they are part of this church'. In this early publication, Calvin does not say anything about 'double predestination'. He argues that election is 'in Christ' and that inquiry into the reasons for non-election is fruitless (Neuser 2008:307-309).

In his First Catechism (Hesselink 1997 [1538]), Calvin explained in article 13 the notion of predestination. In this catechism one can see a further development of his thoughts already mentioned in the Institutes of 1536. This article follows article 12 which deals with faith that grasps Christ. Therefore, early Calvin did not treat predestination as a central theological theme. In article 13, he makes the following important remarks. Calvin starts off by saying that the reason why some believe and others do not believe is a secret of the divine plan (Hesselink 1997 [1538]):

For the seed of God's Word takes root and bears fruit only in those whom the Lord has by his eternal election predestined as his children and heirs of the kingdom of heaven; for all the rest, who were condemned by this same plan of God before the foundation of the world, the utterly clear preaching of truth can be nothing but the stench of death unto death. Now why should the Lord deem the former worthy of his mercy but exercise his severe judgement on the latter? Let us leave the cause in his hand, for he has for the best reasons willed to hide it from us [...]. Only let us acknowledge among ourselves that this dispensation of the Lord, although hidden to us, is nonetheless just and holy. For if he were to destroy all mankind, he would only be doing so by his own right. If those he calls back from perdition one can see nothing but his supreme goodness. Let us therefore recognize the elect to be vessels of his mercy; the reprobate the vessels of his wrath, but a just wrath indeed. (p. 17)

15.The reformed theologian, Otto Weber (1972 [1962]:458-563) and the Lutheran the theologian, Wolfhart pannenberg (193:473-500), are two systematic theologian of the recent theme of election. Kim's dissertation (2013) is also a valuable contribution in this regard. He shows that election is biblically based on election of groups and peoples.
There is, however, another statement that should not be ignored. Ultimately, Calvin (Hesselink 1997 [1538]) explains election and predestination from the perspective of Christ:

Just as all who before the foundation of the world were foreordained to life were chosen in Christ, so it is he in whom the pledge of our election is set forth to us. Accordingly, we receive and embrace him in faith [...]. But if while possessing Christ in faith, we at the same time possess life in him, we have no business investigating anything beyond this concerning God's eternal plan. For Christ is not simply the mirror wherein God's will is shown to us, but the pledge wherewith it is, so to speak, sealed. (p. 17)

In the Institutes of 1539, Calvin has already finalised his position on predestination - at least in terms of the dogmatic exposition. In chapter 8, 'De praedestinatione et providentia', Calvin first deals with election and then providence. In the 1559 version of the Institutes, the two themes were totally separated. In both the 1539 and 1559 versions, predestination is discussed as a theme after law, faith, repentance and justification. Calvin therefore has a soteriological aim with predestination. He wants to provide the believer with certainty concerning faith. He gives the assurance that the believers are the elect. For this reason, he explicitly concentrates on the motive of election in and through Christ. He also comforts the pious that God who elects them will also provide in their earthly needs (Brouwer 2016:45-46; Neuser 2008:311-312).

In his Genevan Catechism of 1545, Calvin deals with the question of election and predestination in the question concerning the kingdom of God in the second petition (question and answer 269). Calvin ([1545] 1867) explains this petition as follows:

Duobus potissimum membris constat. Ut electos spiritu gubernet suo: ut reprobos, qui se illi in obsequium trader recusant, prosternat, et exitio tradat: ut ita palam fiat, nihil esse, quod resistere eius virtuti queat. [It consists chiefly of two branches - that he would govern the elect by his Spirit - that he would prostrate and destroy the reprobate who refuse to give themselves up to his service, thus making it manifest that nothing is able to resist his might.] (col. 96 [author's translation])

These harsh words are some of the first steps in the direction of his heartless doctrine of double predestination.

Although Calvin treated predestination as an important biblical theme, he also had to give expositions on the theme, because it became one of the controversies he had to deal with (cf. Gamble 2004 for an overview). In his work, Against Pighius of 1543, he gave attention to the question of the free will, but could not attend to predestination itself. Jerome Bolsec, a former monk and court physician outside of Geneva, however, forced him to clarify his position on predestination. He accused him of making God the author of sin. In discussions among the ministers it became clear that the real issue on the table was the universality of salvation. The controversy with Bolsec led Calvin to address the issue of predestination more fully. He (Calvin [1552] 1961) did so by 
writing Concerning the Eternal Predestination of God (De aeterna Dei praedestinatione). In it he returns to his debate with Pighius which happened nine years before. This is the largest and most sustained treatment Calvin wrote on the doctrine of predestination. This publication is treated by some churches as a reformed confession. Neuser (2008:312) therefore refers to it as the Consensus Genevensis.

There is little of importance in this publication that is not found in the 1559 version of Calvin's Institutes. What needs attention here, is his argument concerning double predestination in relation to faith. This argument (Eph 1:4) of Calvin ([1552] 1961) against Pighius is typical of his thought:

Now I hear Pighius babble something: The whole human race is chosen in Christ, so that whoever should lay hold of Him by faith may obtain salvation. But in this invention there are two gross errors which can be instantly refuted by the words of Paul. For first there is certainly a mutual relation between the elect and the reprobate, so that the election spoken of here cannot stand, unless we confess that God separated out from others certain men as second good to Him. It is this that is expressed by the word predestinating, afterwards twice repeated. Further he calls those chosen who are by faith engrafted into the body of Christ; and that this is something not common to all men is plain. Paul therefore refers to those only whom Christ condescends to call after they have been given to Him by the Father. To make faith the cause of election is quite absurd and at variance with the words of Paul. For as Augustine wisely observes, he does not call them elect because they are about to believe, but in order that they may believe; he does not call them elect whom God foresaw would be holy and immaculate, but in order that they might be made so. (p. 68-69)

In the Institutes of 1559, Calvin had his final say on double predestination. ${ }^{16}$ Some of his statements fill present-day scholars with discomfort. ${ }^{17}$ One example is the following (Inst III.24.12):

As God by the effectual working of his call to the elect perfects the salvation to which by his eternal plan he has destined them, so he has his judgement against the reprobate, by which he executes his plan for them. What of those, then, whom he created for dishonour in life and destruction in death, to become the instruments of his wrath and examples of his severity? That they may come to their end, he sometimes deprives them of the capacity to hear his word; at other times he, rather, blinds and stuns them by the preaching of it. (p. 978)

Calvin's teaching on predestination should, however, not be reduced to his view on double predestination. Calvin actually has two sets of teachings that seems to be in conflict

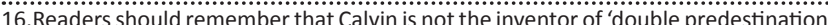
Medieval theologians such as Gregory of Rimini and Gugolino of Orvieto worked with this notion long before Calvin (McGrath 1998 [1990]:168).

17.The discomfort has inter alia to do with the logical consequences of the argument. One consequence is that one has to accept that God wants to eternally punish the
sinner. Jan Bonda (1998 [1993]) is one of the protesters against this image of God. Another objection has to do with the character of God's love. God's love does not exclude anyone beforehand. Double predestination derives from an abstract view of God's almightiness and not his active deed of loving. The church cannot teach an election to damnation, but only an election to salvation (Härle 2000 [1995]:506509). Ott (1981 [1972]:231-237) argues that in a time where the main religious $509)$. Ott (1981 [1972]:231-237) argues that in a time where the main religious
question has to do with the meaning of life, one cannot confront secularised people with this type of doctrinal thinking. with one another, but is not (Link 2009:44-51). On the one side we have the dogmatic teaching on double predestination, and on the other side there is the pastoral approach that concentrates on the grace of God. One finds (according to Neuser 2008:316-317) the first version in his Institutes and the second version in his sermons. This is not completely accurate. One does find the second pastoral approach in the Institutes too. In the footsteps of Augustine, Calvin explains predestination from the perspective of God's mercy and grace in Christ.

In his preface to the first edition of the Institutes (March 1536), Calvin defended the evangelical cause against the charge of novelty. Throughout his academic career he tried to convince people that the Protestant movement was a return to the Early Church and the theology of the church fathers. In the Opera omnia of Calvin (CO) there are more than 3200 references to the Early Church fathers, and 1700 of them refer to Augustine. Many of these references are quotations (Gerrish 2004:291). Calvin therefore saw himself as a scholar standing in the legacy of Augustine. His reflections on predestination were born from his readings of Augustine (cf. MacCulloch 2005 [2003]:109-110, 242-243). Augustine taught Calvin that predestination is nothing but the celebration of divine grace. Conversion to God as well as faith in God can never be a human achievement. It is only a gift of grace. We have nothing that we do not receive. It was especially one of Augustine's last writings, the antiPelagian treatise On the predestination of the saints (AD 428; see Augustine 1887), that formed his opinion on predestination. Augustine's argument is that if a person comes to faith, it is because the Lord prepares the will of that person he has chosen for himself. Ability to believe (fidem posse habere), is a gift of nature; believing (fidem habere) is the gift of a special grace, given only to God's elect (Gerrish 2004:291-292). For Calvin too, the divine election is the final proof that everything is grace - the divine division between those who believe and who do not believe. He (Inst III.21.1) says:

We shall never be clearly persuaded, as we ought to be, that our salvation flows from the wellspring of God's free mercy until we come to know his eternal election, which illumines God's grace by this contrast: that he does not indiscriminately adopt all into the hope of salvation but gives to some what he denies to others. (p. 921)

Calvin, clearly shares Augustine's view that the gratuitousness of God's grace is fundamental, and the eternal election of grace explains the observed fact that some accept the gospel while others don't. Calvin further agrees with Augustine that, while the division between the elect and the non-elect is inescapably, the teaching of Scripture - the reason why God chooses some and not all - is hidden in God's inscrutable justice.

Calvin, however, did not agree with Augustine in all regards (cf. Gerrish 2004:292-293 for an overview of the disagreements). The most important point of disagreement is that Augustine held that none can know whether or not they 
are elect, while Calvin, by contrast, argues that predestination establishes assurance of salvation. Calvin therefore also has a pastoral approach to this dogmatic question. This approach is found in his sermon of 1551 on predestination.

In the light of the conflict with Bolsec, the Compagnie des Pasteurs decided that Calvin should preach $^{18}$ on predestination during Holy Communion. He did so on 18 December 1551 in the Congrégation (CO 8, 85-140; Neuser 2008:313-316). The sermon mainly deals with Bolsec's thesis that election follows faith. Calvin argues that election precedes faith. In his sermon he explains four texts, namely Romans 8:28-29, Ephesians 1:4-5, John 6:44, 10:28, and Romans 9:1-29. In the sermon he has another explanation of Ephesians 1:4-5 than in the Institutes of 1539 and the Consensus Genevensis. Here the argument is pastoral and soteriological. He reminds us that human sinfulness should be taken into account when speaking about predestination. When God looks at the human race, he finds only $\sin$ and disgrace. He is therefore not unjust when he elects only a few. 'Heilspartikularismus' [that only a few are saved] is according to Calvin not cruelty. He says that the elect are elected in Christ. Here his argument ends and he says nothing about election before the beginning of time. Calvin assures believers in Christ that they are elected and that they should not doubt this. He reaffirms that we are not elected because we believe. We should rather accept God's gift of grace by believing that God has already elected us. According to Brouwer (2016:48) it is also important to take the political context of exile into account. By doing this, one will realise that Calvin's sermon also had a dimension of consolation. Election was consolation to uprooted and displaced people and not an intellectual game.

\section{Comparing Luther to Calvin}

Both Luther and Calvin are convinced that predestination is biblical and therefore useful to believers. Their respective teachings on predestination are not born out of eagerness to speculate, but obedience to Scripture (Exalto 1982:157-158; Nürnberger 2005:57-64). Not one of them treats predestination as an article of faith, but as the final outcome of scripturally informed reflection on the effects of grace upon individuals in light of the enigmas of experience. Experience teaches that God does not touch every human heart. Predestination clarifies this human reality (McGrath 1998 [1990]:168).

Both of them teach that predestination is God's mystery. We cannot uncover this mystery by human reason. We can only accept what God has done in Jesus Christ. The mystery-character of this doctrine does not mean uncertainty in terms of salvation. Through faith in Christ we are certain about our eternal destination (Bouwsma 1988:172-174; Elert 1988 [1940]:459-464; Iwand 1983 [1974]:90-104; Wendel 1980 [1950]:277-284).

In spite of the fact that Calvin does not use the same terminology as Luther, he has the same argument on the

18.In older expositions on his doctrine of election such as those of Otten (1968 [1938]), his sermon does not feature prominently. hidden and revealed God. ${ }^{19}$ Both of them argue that we do not know the reasons for God's election and rejection; we simply do not know him as being. We, however, know him through his revelation in Christ. In Christ, he appears as the loving and merciful God (Otten 1968 [1938]:132-135).

Many scholars in the past concentrated on some of Calvin's arguments which state that God has from eternity elected only some people for salvation. With this argument in hand, they argued that Calvin and Luther do not teach the same theology. According to them, Luther teaches that God has revealed himself in Christ as the God of mercy and that those who accept his offer of grace could be certain that they are elected (e.g. Bayer (2007 [2003]:188-189). There could be no doubt about the fact that Calvin teaches the same message. When the whole Calvin is taken into account, the differences between the two are minimal. Wilhelm Niesel (1938:152-173) has proven this even before the Second World War. Calvin does not teach a syllogismus practicus - and when this misunderstanding is removed, one discovers that the two reformers' teachings are almost exactly the same.

One point of difference is that Calvin's doctrine of predestination has shown to have huge ethical consequences. His doctrinal understanding liberated people from fatalism. This freedom gave the Huguenots the courage to endure persecution and to resist tyranny (perseverantia sanctorum). The unity of predestination and responsibility is one of the unique characteristics of Calvin's theology (Hesselink 2004:84). Predestination never had the same socio-political impact on Luther's followers as it had on the followers of Calvin.

\section{Final remark}

Election and predestination are biblical themes. Both the Old and New Testament deal with these themes. Present-day scholars find it difficult to defend the reformers' expositions of these notions. Especially, Calvin's double predestination does not find apologists. In the light of the radical critique of the Enlightenment, Schleiermacher and Barth proposed new ways of explaining and defending these notions. Barth's tendency to embrace the idea that all would eventually be saved (Allversöhnung) is also not biblical. Calvin's focus on the eternal election of God should not be discarded easily. This teaching is a reminder of God's freedom. God's grace cannot be bound or controlled by any creature - even as God's love is freely offered to us in the gospel by the Holy Spirit (Brunner 1960 [1946]:318; Zachman 2016:147). New approaches to these themes will have to be developed. With Mildenberger (2005:199) I would suggest that the perspective of our election in Christ is at the centre of any endeavour. One should also fall back on Calvin's early position of embedding election in ecclesiology. In this way the important theme of 'covenant' could come into play (Kim 2013:227-230;

19. Exalto's argument (1982:177) that Luther speaks in dualistic terms about God and Calvin not, does not touch the heart of the argument concerning the hidden and the revealed God. Both of them speaks about the comprehensible and the incomprehensible word of God, and not about two Gods. 
Link 2009:75-96) The praise of the congregation of its election can create certainty in a world of uncertainty, but also leave open the hope that others may also share in eternal redemption.

\section{Acknowledgements Competing interests}

The author declares that he has no financial or personal relationships which may have inappropriately influenced him in writing this article.

\section{References}

Augustine, 1887, On the predestination of the saints, transl. P. Holmes \& R.E. Wallis, rev, B.B. Warfield, ed. P. Schaff, Christian Literature Publishing Co, Buffalo, NY, (Nicene and Post-Nicene Fathers, 1st series, vol. 5), viewed 14 December 2017 (Nicene and Post-Nicene Fathers, 1st series, vol. 5), viev
from http://www.newadvent.org/fathers/15121.html

Barth, H-M., 2009, Die Theologie Martin Luthers: Eine kritische Würdigung, Gütersloher Verlagshaus, Gütersloh.

Bayer, O., 2007 [2003], Martin Luthers Theologie: Eine Vergegenwärtigung, 3. Erneut durchgesehene Aufl., Mohr Siebeck, Tübingen.

Bonda, J., 1998 [1993], The one purpose of God: An answer to the doctrine of eterna punishment, transl. R. Bruinsma, Eerdmans, Grand Rapids, MI.

Bouwsma, W., 1988, John Calvin: A sixteenth century portrait, Oxford University Press, Oxford.

Brouwer, R., 2016, 'Election', in P. Nimmo, \& D. Fergusson (eds.), The Cambridge companion to reformed theology, pp. 44-59, Cambridge University Press, Cambridge.

Brunner, E., 1960 [1946], Dogmatik Band 1. Die christliche Lehre von Gott, 3. Aufl., Zwingli Verlag, Zürich.

Calvin, I., 1867 [1545], 'Catechismus ecclesiae Genevensis', in G. Baum, E. Cunitz \& E. Reuss (eds.), Corpus Reformatorum, volumen XXXIV, Opera quae supersunt omnia, pp. 313-362, Apud C.A. Schwetschke et Filium, Brunsvigae.

Calvin, L, 1887, loannis Calvini Opera quae supersunt omnia, ed. G. Baum, E. Kunitz \& E. Reuss, Schwetschke et Filium, Braunschweig. (Corpus Reformatorum, 29-88).

Calvin, J., 1961 [1552], Concerning the eternal predestination of God, transl. J. Reid, Westminster John Knox, Louisville, KY.

Calvin, J., 1963 [1536], 'Institutes of the Christian religion', in P. Barth \& W. Niesel (ed.), Joannis Calvini Opera Selecta, vol. 1, Scripta Calvini ab anno 1533 usque ad annum 1541 continens, Chr. Kaiser Verlag, München.

Calvini, I., 1864 [1559], 'Institutio Christianae Religionis', in G. Baum, E. Cunitz, \& E. Reuss (eds.), Libros quatuor nunc primum Digesta certisque distincta Capitibus, ad aptissimam Methodum, Aucta etiam tam magna Accessione ut Propemodum Opus novum haberi possit, Corpus Reformatorum, vol. XXX, Apud C.A. Schwetschke et Filium, Brunsvigae. (Theologi Argentoratenses, vol. II).

CO see Calvin 1887

Ebeling, G., 1979, Dogmatik des christlichen Glaubens. Band III, Mohr Siebeck, Tübingen.

Elert, W., 1988 [1940], Der christliche Glaube: Grundlinien der lutherischen Dogmatik. 6. Aufl., Martin-Luther-Verlag, Erlangen.

Exalto, K., 1982, 'Luthers leer van de pradestinatie', in C. Graafland, J. Kamphuis, W. Van't Spijker \& K. Exalto (eds.), Luther en die Gereformeerd Protestantisme, pp. 157-182, Boekencentrum, 's-Gravenhage.

Gamble, R., 2004, 'Calvin's controversies', in D. McKim (ed.), The Cambridge companion to John Calvin, pp. 188-203, Cambridge University Press, Cambridge.

Gerrish, B., 2004, 'The place of Calvin in Christian theology', in D. McKim (ed.), The Cambridge companion to John Calvin, pp. 289-304, Cambridge University Press, Cambridge.

Härle, W., 2000 [1995], Dogmatik, 2. überarbeitete Aufl., De Gruyter, Berlin.

Härle, W., 2006, 'Einleitung', in W. Härle (Hrsg.), Martin Luther: Lateinisch-Deutsche Studienausgabe, Band 1, Der Mensch vor Gott, Unter Mitarbeit von Miachael Beyer, pp. XI-XLII, Evangelische Verlagsanstalt, Leipzig.

Hesselink, J., 1997 [1538], Calvin's First Catechism: A commentary. Featuring Ford Lewis Battle's translation of the 1538 Catechism, John Knox Press, Louisville, $\mathrm{KY}$. (Columbia series in reformed theology).

Hesselink, J., 2004, 'Calvin's theology', in D. McKim (ed.), The Cambridge companion to John Calvin, pp. 74-92, Cambridge University Press, Cambridge.

Inst see Calvin 1864 [1559]

Iwand, H.J., 1983 [1974], Nachgelassene Werke. Band 5. Luthers Theologie, Hrsg. J. Haar, Chr. Kaiser, München.

Jüngel, E., 1980, 'Quae supra nos, nihil ad nos: Eine Kurzformel der Lehre vom verborgenen Gott - im Anschlu $\beta$ an Luther interpretiert', in E. Jüngel (ed.), Entsprechungen: Gott - Wahrheit - Mensch: Theologische Erörterungen, pp. 202-261, Chr. Kaiser, München.
Kim, M., 2013, Die umstrittene Prädestinationslehre: Luther - Calvin - Barth Neukirchener Theologie, Neukirchen-Vluyn.

Kolb, R., Dingel, I. \& Batka, L. (eds.), 2016, The Oxford handbook of Martin Luther's theology, Oxford University Press, Oxford.

Leppin, V., 2010 [2006], Martin Luther, 2. durchgesehene, aktualisierte Aufl. Wissenschaftliche Buchgesellschaft, Darmstadt. (Gestalten des Mittelalters und der Rennaissance, Herausgegeben von Peter Herde).

Link, C., 2009, Prädestination und Erwählung: Calvin-Studien, Neukirchener Verlag, Neukirchen-Vluyn

Lohse, B., 1999 [1995], Martin Luther's theology: Its historical and systematic developments, transl. and ed. R. Harrisville, T\&T Clark, Edinburgh.

Luther, M., 1912 [1538/1542], D. Martin Luthers Werke, Kritische Gesamtausgabe, Genesisvorlesung. Cap. 18-30, 43. Band, Hrsg. J.K.F. Knaake, Hermann Böhlaus Nachfolger, Weimar.

Luther, M., 1913 [1531-1546], D. Martin Luthers Werke. Kritische Gesamtausgabe. Tischreden 1531-1546, 2. Band, Hrsg. J.K.F. Knaake und Nachfolger, Herman Böhlaus Nachfolger, Weimer.

Luther, M., 1919 [1531-1546], D. Martin Luthers Werke. Kritische Gesamtausgabe. Tischreden 1531-1546, 5. Band, Tischreden aus den Jahren 1540-1544, Hrsg. J.K.F. Knaake und Nachfolger, Herman Böhlaus Nachfolger, Weimer.

Luther, M., 2006 [1525], 'De servo arbitrio', in W. Härle (Hrsg.), Martin Luther Lateinisch-Deutsche Studienausgabe, Band 1, Der Mensch vor Gott, Unter Mitarbeit von Miachael Beyer, pp. 219-661, Evangelische Verlagsanstalt, Leipzig.

Luther, M., 2012 [1519], 'Ein Sermon von der Bereitung zum Sterben', in D. Korsch (Hrsg.), Martin Luther: Deutsch-Deutsche Studienausgabe, Band 1 Glaube und Leben, pp. 48-73, Evangelische Verlagsanstalt, Leipzig.

MacCulloch, D., 2005 [2003], The reformation: A history, Penguin Books, New York, NY

McCormack, B., 1999, 'The sum of the gospel: The doctrine of election in the theologies of Alexander Schweizer and Karl Barth', in D. Willis \& M. Welker (eds.), Toward the future of reformed theology: Tasks, topics, traditions, pp. 470-493, Eerdmans, Grand Rapids, MI.

McGrath, A., 1998 [1990], A life of John Calvin: A study in the shaping of Western culture, 6 th printing, Blackwell Publishers, Oxford.

Melanchthon, P., 2011 [1559], The chief theological topics, transl. J.A.O. Preus from the original Loci Praecipui Theologici, 2nd English edn., Concordia Publishing House, St. Louis, MO

Mildenberger, F., 2005, 'Gottes Heilsplan - Erwählung und Geschichte', in E. Maure (Hrsg.), Grundlinien der Dogmatik. Festschrift für Gerhard Sauter zum 70. Geburtstag, pp. 181-199, CMZ-Verlag, Rheinbach.

Muller, R., 2013, 'John Calvin and later Calvinism: The identity of the reformed tradition', in D. Bagchi \& D. Steinmetz (eds.), The Cambridge companion to reformation theology, pp. 130-149, Cambridge University Press, Cambridge.

Neuser, W., 2008, 'Prädestination', in H. Selderhuis (Hrsg.), Calvin Handbuch, pp. 307-317, Mohr Siebeck, Tübingen.

Niesel, W., 1938, Die Theologie Calvins, Chr. Kaiser, München.

Nürnberger, K., 2005, Martin Luther's message for us today: A perspective from the South, Cluster Publications, Pietermaritzburg.

OS 1 see Calvin 1963 [1536]

Ott, H., 1981 [1972], Die Antwort des Glaubens: Systematische Theologie in 50 Artikeln, 3. Überarbeitete und erweiterte Aufl, Hrsg. v K. Otte, Kreuz, Stuttgart.

Otten, H., 1968 [1938], Prädestination in Calvins theologischer Lehre, Neukirchener Verlag des Erziehungsvereins, Neukirchen-Vluyn.

Pannenberg, W., 1993, Systematische Theologie. Band 3, Vandenhoeck \& Ruprecht, Göttingen.

Plasger, G., 2008, Johannes Calvins Theologie - Eine Einführung, Vandenhoeck \& Ruprecht, Göttingen.

Rieger, R., 2017, Martin Luthers theologische Grundbegriffe: Von "Abendmahl" bis "Zweifel", Mohr Siebeck, Tübingen. (UTB 4871).

Schwarz, R., 2014 [1986], Luther, 4. durchgesehene Aufl., Vandenhoeck \& Ruprecht, Göttingen. (UTB 1926).

Schweizer, A., 1844, Die Glaubenslehre der evangelisch-reformierten Kirche, vol. 1 , Orell, Füssli und Comp., Zürich.

Trueman, C., 2013, 'The theology of the English reformers', in D. Bagchi \& D. Steinmetz (ed.), The Cambridge companion to reformation theology, pp. 161-173, Cambridge University Press, Cambridge.

Van Wyk, N., 2015, 'Die predestinasieleer: Geen rede tot kommer nie', Tydskrif vir Hervormde Teologie 3(4), 9-25.

Weber, O., 1972 [1962], Grundlagen der Dogmatik. Band II. 2. Aufl., Neukirchener Verlag, Neukirchen-Vluyn.

Wendel, F., 1980 [1950], Calvin: The origin and development of his religious thought, transl. P. Mairet, William Collins \& Sons Co Ltd, Glasgow.

Wriedt, M., 1991, Gnade und Erwählung: Eine Untersuchung zu Johann von Staupitz und Martin Luther, Wissenschaftliche Buchgesellschaft, Darmstadt.

Zachman, R., 2016, 'John Calvin', in P. Nimmo \& D. Fergusson (eds.), The Cambridge companion to reformed theology, pp. 132-147, Cambridge University Press, Cambridge. 